\title{
Zoom Cloud Meeting-Based Learning Model Needs Analysis to Improve Mathematical Communication Ability of Elementary School Students
}

\author{
Naili Darojatil Lathifah ${ }^{1}$, Rusdarti' ${ }^{2}$, Rochmad ${ }^{2}$ \\ ${ }^{1}$ Mathematics Education Program, Universitas Islam Negeri Walisongo Semarang, Semarang, Indonesia. \\ ${ }^{2}$ Primary School Education Program, Postgraduate School of Universitas Negeri Semarang, Semarang, \\ Indonesia. \\ Corresponding Author: Naili Darojatil Lathifah
}

\begin{abstract}
The purpose of this research is to analyze and describe the video conferencing application technology-based learning via zoom cloud meeting to improve students' mathematical communication ability based on the perspective of educators or teachers. The research was conducted using a qualitative descriptive method with an emphasis on needs analysis. Techniques of data collection were carried out with several instruments including interviews, documentation, questionnaires, and tests related to students' mathematical communication ability given to several students with the assistance of their respective teachers. The results of interviews and initial observations in this research indicate that $80 \%$ of teachers still use assignments as tools to determine students' mathematical communication ability, and $67 \%$ of students' mathematical ability has decreased compared to that of prior to the pandemic, so a learning model is needed in accordance with current educational conditions, particularly in improving students' mathematical communication ability. Therefore, the selection of the application of a problem-based learning model with a realistic mathematical approach in zoom cloud meeting-based learning is expected to improve the communication ability of elementary school students.
\end{abstract}

Keywords: Zoom, PBL, Realistic mathematics, mathematical communication.

\section{INTRODUCTION}

Education constitutes an effort to create an atmosphere of teaching and learning process, so students can actively develop their abilities and skills in their roles within the society. In Indonesia, the level of education unit considered as the basis of education is at the elementary school level (1). In elementary school, students experience a teaching and learning process, which in general, in its implementation process students are prepared for the next level of education. Basic education is held to provide basic knowledge, attitudes, and skills for students, which is further developed to improve the quality of students' personality where the implementation is carried out in formal classes or schools (2).

As the pandemic condition progresses, learning in Indonesia has also made changes, one of which is online learning process at students' respective homes $(3,4)$. Indirectly, this positively impacted on the community to update knowledge regarding technology that supports the smooth teaching and learning process, especially for educators or teachers and students, even though they are only at home and with their families (5-7). One of the technologies often used today is online video conferencing application via zoom cloud meeting which functions as a communication tool, which according to 
Naili Darojatil Lathifah et.al. Zoom cloud meeting-based learning model needs analysis to improve mathematical communication ability of elementary school students.

educators or teachers is easier to use than other online video conferencing applications (8-12).

Roles of the teachers in the teaching and learning process are very essential, other than being facilitators in its implementation, teachers are also required to master various learning models that can support all students' abilities. Especially for elementary school students whose thinking process is still in the concrete stage, the teachers must adapt to online learning which is more likely to lead to concrete-abstract stage learning (13).

One of the mathematical skills that needs to be developed to support progress in mathematics is communication ability. The communication ability in mathematics is students' skills in expressing mathematical ideas/mathematical symbols, ability to understand, interpret, and explain mathematical terms and notations, both orally and in writing (14). The students' mathematical communication ability can occur if the learning process occurs in twoway communication, one of which is through discussion, namely through discussion and group learning students can communicate their thoughts to classmates and teachers.

Besides being stated in the objectives of learning mathematics at school, mathematical communication ability is needed to train thinking patterns and reasoning in drawing conclusions, developing ability to solve problems, as well as developing ability to provide information (15), mathematical communication ability is also in accordance with the development of science and technology in the 21st century, which requires students to be able to compete globally. This conforms with the curriculum goal to prepare students to master 21st century skills.

Pursuant to the results of interviews and observations with elementary school teachers in elementary schools in Trangkil Subdistrict, Pati Regency, Central Java Province, it is known that $80 \%$ of elementary school teachers are currently learning by using assignments given to students via short messages or via share groups. Face-to-face learning has never been conducted even though the internet data quota assistance from the government is sufficient for face-to-face learning using video conferencing. The task instruments given to students are also not optimal in developing students' mathematical communication ability.

Based on this background, this research aims to analyze and describe how video conferencing application technology via zoom cloud meeting can improve students' mathematical communication ability from the perspective of educators or teachers.

\section{LITERATURE REVIEW}

This research was conducted based on research that has been done previously by several researchers. Previous research that is considered relevant to this research is research from Niasih (2019), Khadijah (2018), Ashim (2019), and Rahmawati (2019) which explains the importance of analyzing students' mathematical communication skills so that teachers or prospective teachers can further develop their skills. students' mathematical communication in accordance with the criteria of these students and the need to develop students' mathematical communication skills (16-19).

Subsequent research conducted by Ningrum (2017) and Sukmawati (2020) stated that one of the learning models that are suitable for the development of students' mathematical communication is a problembased learning model $(20,21)$. The results of this study are supported by research by Aufa (2016), Perwitasari (2017), and Putri (2019) with research results showing that the development of mathematical communication skills is one of the focuses of problem-based learning (22-24).

The research of Sayem (2017), Guzachchova (2020), and Haqien (2020) shows that the use of online applications 
Naili Darojatil Lathifah et.al. Zoom cloud meeting-based learning model needs analysis to improve mathematical communication ability of elementary school students.

based on video converence via Zoom Meeting has proven to be effective in improving the quality of student learning $(8,10,11)$. The results of this study are corroborated by research conducted by Hamidy (2021) which explains that the results of learning mathematics using Zoom Meeting are better than Google Classroom (12).

\section{MATERIALS \& METHODS}

This study used descriptive qualitative method. Qualitative research using descriptive method aims to solve actual problems faced and collect data or information to be compiled, explained, and analyzed (25). The research was conducted to elementary school teachers in Trangkil Subdistrict, Pati Regency. Data collection was carried out with several instruments including interviews, documentation, and questionnaires given to several teachers regarding students' mathematical communication ability during the pandemic. Research subjects used in this study were determined through purposive sampling technique, research subjects were selected based on certain characteristics, namely elementary schools with high levels of learning through assignments.

The analysis process used a needs analysis related to the importance of using a zoom cloud meeting-based learning model in improving the mathematical communication ability of elementary school students and the use of literature methods as reinforcement of research data.

\section{RESULT AND DISCUSSION}

Drastic changes in the current learning process indirectly make teachers and students inevitably have to learn from each other as well as teach each other in updating existing technological knowledge (7). Education in Indonesia is currently very dependent on online applications that support learning, especially those supported by the video conferencing features, so it can indirectly carry out face-to-face learning between teachers and students. One of the online applications supported by the video conferencing features is zoom cloud meeting. However, the lack of mastery of video conferencing-based learning models makes learning less effective and efficient, especially in improving students' mathematical communication ability in elementary school mathematics lessons. Therefore, it is necessary to develop a zoom cloud meeting-based learning model based to improve the mathematical communication ability of elementary school students.

\section{Zoom Cloud Meeting Application}

The zoom application is a software (a platform) created by Eric Yuan that functions as a communication medium in the form of written, spoken, and video that offers several useful and low-cost and userfriendly features that suit users' needs $(26,27)$.

Based on interview data and questionnaires, it is known that $80 \%$ of teachers in Trangkil Subdistrict only use assignments given via SMS, and $70 \%$ of students do not understand assignments assigned by their teachers. This can be seen from the results of students' assignments answered incorrectly. Therefore, a more effective way is needed to help the student learning process, one of which is the zoom cloud meeting application.

There are several zoom cloud meeting features that support the teaching and learning processes, including the raise hand feature that makes it easier for students or participants of the zoom cloud meeting to raise questions in the explanation session, the screen sharing feature which aims to make all students or participants of the zoom cloud meeting know the contents of the teacher's screen, so students can more easily catch the teacher's explanation or vice versa, namely making it easier for students to present works, the white board feature that functions for teachers to write or draw on the white field provided, and the teacher can also add writing, signs, or pictures on the previous share screen which has been 
Naili Darojatil Lathifah et.al. Zoom cloud meeting-based learning model needs analysis to improve mathematical communication ability of elementary school students.

done, the chat feature that functions for students or zoom participants who want to express their ideas or raise questions in writing, the breakout room feature which is a feature to divide the classes into different rooms as dividing students into several groups during a group discussion session, and the session recording feature, which is a feature that serves to recap all learning activities, as well as a link to YouTube feature, so students who cannot take part in the current learning can better access it via YouTube $(28,29)$.

\section{Mathematical Communication Ability}

Communication is a very important skill in human life, so this ability becomes one of the objectives of implementing learning activities in schools. NCTM (National Council of Mathematics Teachers) has established the communication as one of the standards in the mathematics learning process in schools (30). Besides, communication ability is needed to convey thoughts, expand students' understanding of mathematical concepts by writing, explaining, giving reasons, and processing thoughts concerning mathematics (31).

Contrary to the above description, from data on students' mathematical communication ability obtained by the teachers through assignments and questions and answers via short messages, it is known that only $24 \%$ of students understand and comprehend materials being studied. This has proven that mathematical communication ability has decreased as much as $67 \%$ of students' mathematical communication ability prior to the pandemic, which is 91\%. This situation makes teachers feel the need to find ways to improve the learning process to restore students' mathematical communication ability.

This is not easy due to several things that must be considered in improving students' mathematical communication ability. Some general mathematical communication indicators are written as follows (32).
1. Connecting real objects, pictures, and diagrams into mathematical ideas.

2. Explaining mathematical ideas, situations, and relations orally or in writing with real objects, pictures, graphs, and algebra.

3. Expressing everyday events in the symbolic language of mathematics.

4. Listening, discussing, and writing about mathematics.

5. Reading with understanding a written mathematical presentation.

6. Making conjectures, compiling arguments, formulating definitions and generalizations.

7. Explaining and creating questions about the mathematics learned.

\section{Zoom Cloud Meeting-Based Learning Model to Improve Mathematical Communication Ability of Elementary School Students}

Roles of the learning model in the teaching and learning process cannot be separated from the roles of the teachers. Teachers' mastery of the learning model is very influential on the effectiveness and efficiency of a learning (33). On the other hand, as the impacts of the COVID-19 pandemic, one of which is the lack of teacher preparation regarding knowledge and mastery of learning models that can be used during online learning (34). Lack of preparation before conducting online learning also has an impact on less optimal teaching and learning process. It is required additional training or guidance for teachers to better know and master the situation as required to do online learning (35).

One of the online application platforms that can optimize the remote teaching and learning process is zoom cloud meeting $(8,36,37)$. Besides being able to carry out face-to-face learning, teachers can also apply learning models in accordance with the materials. The use of zoom cloud meeting includes synchronous learning, where teachers and students can carry out face-to-face activities at the same time through computers, laptops, or smartphones 
Naili Darojatil Lathifah et.al. Zoom cloud meeting-based learning model needs analysis to improve mathematical communication ability of elementary school students.

(38-40). Teachers can also conduct an assessment immediately after the lesson ends without having to end the face-to-face process, so the teachers know the character of each student during working on the assessment. One of the learning models that can support the teaching and learning process based on zoom cloud meeting is problem-based learning. The steps of problem-based learning model activities can be carried out through zoom cloud meeting, namely orienting students to problems, organizing students to study, assisting independent or group investigations, developing and presenting work results, analyzing and evaluating problem solving processes $(41,42)$. In previous research, the problem-based learning model was proven to improve students' mathematical communication ability (20). Previous research still used classroom facilities as a place for learning to be carried out, so it is necessary to renew problem-based learning models to be more effective even without direct face-to-face facilities. Therefore, the current researcher decided to use a realistic mathematical approach.

Realistic mathematics is an approach in learning mathematics where the process of delivering materials is related to students' daily lives (24). Several previous studies have proven that a realistic mathematical approach can improve the mathematical communication ability of elementary school students in formal learning or at schools $(43,44)$. The characteristics of the realistic mathematical approach are in accordance with the steps of the problem-based learning model at the stage of organizing students to study, independent or group investigations, and analysis of the evaluation of the problem-solving process. The learning process in the steps of a problem-based learning model with a realistic mathematical approach can encourage students to further improve their mathematical communication ability.

Besides, the zoom cloud meeting application can also support the learning assessment process using a link that can be provided in the chat feature when learning is about to end via Google form, typeform, or others, either in the form of multiple-choice questions or description questions. Direct assessment with the help of link also serves to determine the level of mathematical communication ability of each student, so teachers can directly observe students' development.

\section{CONCLUSION}

The pandemic has greatly impacted the teaching and learning process for both teachers and students. While the ability of teachers in mastering online-based learning models is lacking. Students' needs for learning require teachers to continuously update their knowledge, especially in improving students' mathematical communication ability. There needs to be a renewal of learning models in accordance with current conditions, namely by applying a problem-based learning model with a realistic mathematical approach.

Based on the results of the research analysis, it can be concluded that the zoom cloud meeting-based teaching and learning process by applying a problem-based learning model with a realistic mathematical approach is expected to improve the communication ability of elementary school students.

Acknowledgement: None

\section{Conflict of Interest: None}

\section{Source of Funding: None}

\section{REFERENCES}

1. Sumantri M, Sa'ud US. Pendidikan dasar dan menengah. Indones Dalam Arus Sej VIII. 2003;(021):1-39.

2. Sujana IWC. Fungsi Dan Tujuan Pendidikan Indonesia. Adi Widya J Pendidik Dasar. 2019;4(1):29.

3. Pajarianto H, Kadir A, Galugu N, Sari P, Februanti S. Study From Home In The Middle Of The COVID-19 Pandemic: Analysis Of Religiosity, Teacher, and Parents Support Against Academic Stress. 
Naili Darojatil Lathifah et.al. Zoom cloud meeting-based learning model needs analysis to improve mathematical communication ability of elementary school students.

J Talent Dev Excell [Internet]. 2020;12(2):1791-807. Available from: http://iratde.com/index.php/jtde

4. Dewi WAF. Dampak Covid-19 terhadap implementasi pembelajaran daring di Sekolah Dasar. Edukatif J Ilmu Pendidik. 2020;2(1):55-61.

5. Gladović P, Deretić N, Drašković D. Video Conferencing and its Application in Education. Jtttp - J Traffic Transp Theory Pract. 2020;5(1):45-8.

6. Maatuk AM, Elberkawi EK, Aljawarneh S, Rashaideh H, Alharbi H. The COVID19 pandemic and E-learning: challenges and opportunities from the perspective of students and instructors. J Comput High Educ [Internet]. 2021;(0123456789). Available from: https://doi.org/10.1007/s12528-02109274-2

7. Mishra DL, Gupta DT, Shree DA. Online Teaching-Learning in Higher Education during Lockdown Period of COVID-19 Pandemic. Int J Educ Res Open [Internet]. 2020;100012. Available from: https://doi.org/10.1016/j.ijedro.2020.1000 12

8. Guzachchova Nadezhda. Zoom Technology as An Effective Tool For Distance Learning in Teaching English to Medical Students. Bull Sci Pract [Internet]. 2020;6(5):457-60. Available from:

https://cyberleninka.ru/article/n/zoomtechnology-as-an-effective-tool-fordistance-learning-in-teaching-english-tomedical-students (дата обращения: 19.11.2020)

9. Roberts R. Video Conferencing in Distance Learning: A New Zealand Schools' Perspective. J Open, Flex Distance Learn. 2009;13(1):91-107.

10. Sayem ASM, Taylor B, Mcclanachan M, Mumtahina U. Effective use of Zoom technology and instructional videos to improve engagement and success of distance students in Engineering. Australas Assoc Eng Educ (AAEE 2017) [Internet]. 2017;1(1):1-6. Available from: https://www.researchgate.net/publication/ 323268816_Effective_use_of_Zoom_tech nology_and_instructional_videos_to_impr ove_engagement_and_success_of_distanc e_students_in_Engineering

11. Haqien D, Rahman AA. Pemanfaatan Zoom Meeting untuk Proses Pembelajaran pada Masa Pandemi Covid-19. SAP (Susunan Artik Pendidikan). 2020;5(1).

12. Hamidy A. Zoom Meeting vs Google Classroom: Perbedaan Hasil Belajar Matematika Berdasarkan Platform Pembelajaran Daring. Tarb Wa Ta'lim J Penelit Pendidik dan Pembelajaran. 2021;8(1):61-8.

13. Maher D. Online learning in primary schools. Online Learn Common Misconceptions, Benefits Challenges. 2014; (January 2014):125-35.

14. Asnawati S. Peningkatan kemampuan komunikasi matematis siswa smp dengan pembelajaran kooperatif tipe teamsgamestournaments. Euclid. 2017;3(2).

15. Rizqi NR, Surya E. An analysis of students' mathematical reasoning ability in viii grade of sabilina tembung junior high school. Int J Adv Res Innov Ideas Educ. 2017;3(2):2395-4396.

16. Niasih N, Romlah S, Zhanty LS. Analisis Kemampuan Komunikasi Matematis Siswa SMP di Kota Cimahi Pada Materi Statistika. J Cendekia J Pendidik Mat. 2019;3(2):266-77.

17. Khadijah INA, Maya R, Setiawan W. Analisis kemampuan komunikasi matematis siswa smp pada materi statistika. JPMI (Jurnal Pembelajaran Mat Inov. 2018;1(6):1095-104.

18. Ashim M, Asikin M, Kharisudin I, Wardono W. Perlunya Komunikasi Matematika dan Mobile Learning Setting Problem Based Learning untuk Meningkatkan Kemampuan 4C di Era Disrupsi. In: PRISMA, Prosiding Seminar Nasional Matematika. 2019. p. 687-97.

19. Rahmawati NS, Bernard M, Akbar P. Analisis Kemampuan Komunikasi Matematik Siswa Smk Pada Materi Sistem Persamaan Linier Dua Variabel (SPLDV). J Educ. 2019;1(2):344-52.

20. Ningrum RK. Meningkatkan Kemampuan Komunikasi Matematis Siswa Menggunakan Problem Based Learning berbasis Flexible Mathematical Thinking. Semin Nas Mat X Univ Negeri Semarang 
Naili Darojatil Lathifah et.al. Zoom cloud meeting-based learning model needs analysis to improve mathematical communication ability of elementary school students.

[Internet]. 2017;213-22. Available from: https://journal.unnes.ac.id/sju/index.php/p risma/article/view/21620

21. Sukmawati H. Model Pembelajaran Berbasis Masalah. Ash-Shahabah. 2020;6(1):26-31.

22. Aufa M, Saragih S, Minarni A. Development of Learning Devices through Problem Based Learning Model Based on the Context of Aceh Cultural to Improve Mathematical Communication Skills and Social Skills of SMPN 1 Muara Batu Students. J Educ Pract. 2016;7(24):232-48.

23. Perwitasari D, Surya E. The Development of Learning Material Using Problem Based Learning to Improve Mathematical Communication Ability of Secondary School Students. Int J Sci Basic Appl Res. 2017;33(3):200-7.

24. Putri SK, Hasratuddin H, Syahputra E. Development of Learning Devices Based on Realistic Mathematics Education to Improve Students' Spatial Ability and Motivation. Int Electron J Math Educ. 2019;14(2):243-52.

25. Atmowardoyo H. Research Methods in TEFL Studies: Descriptive Research, Case Study, Error Analysis, and R \& D. J Lang Teach Res. 2018;9(1):197.

26. Hrncirik L, Scanga, Y. MK, Deen, Smith SR, Wright K. Special Issue on Innovation 2018 Zoom Around the World: Using Videoconferencing Technology for. J Ext. 2018;56(5).

27. Walni M. Proses Pembelajaran Masa Pandemi Covid-19 Berbasis Aplikasi Zoom Meeting. 2021;

28. Cuaca Dharma HR, Asmarani D, Dewi UP. Basic Japanese Grammar and Conversation e-learning through Skype and Zoom Online Application. In: Procedia Computer Science. Elsevier B.V.; 2017. p. 267-73.

29. Mubarak MR, Wahdah N, Ilmiana AM, Hamidah H. Zoom Cloud Meeting: Media Alternatif dalam Pembelajaran Maharah Kalam di Tengah Wabah Virus Corona (Covid-19). Arab J Bhs Arab. 2020;4(2): 211-26.

30. Purwanti S. Meningkatkan Kemampuan Komunikasi dan Berpikir Kritis
Matematis Siswa Sekolah Dasar Dengan Model Missouri Mathematics Project (MMP). TERAMPIL J Pendidik dan Pembelajaran Dasar. 2015;2(2):253-66.

31. Rohid N, Suryaman S, Rusmawati RD. Students' Mathematical Communication Skills (MCS) in Solving Mathematics Problems: A Case in Indonesian Context. Anatol J Educ. 2019;4(2):19-30.

32. Hasna L, Aini IN. Analisis Kemampuan Komunikasi Matematis Siswa SMP Pada Materi Bangun Ruang. Pros Sesiomadika. 2020;2(1c).

33. Alawiyah F. Peran Guru dalam Kurikulum 2013. J Aspir [Internet]. 2013;4(1):65-74. Available from: http://jurnal.dpr.go.id/index.php/aspirasi/a rticle/view/480

34. Mastura, Santaria R. Dampak Pandemi Covid-19 terhadap Proses Pengajaran bagi Guru dan Siswa Pendahuluan. J Stud Guru dan Pembelajaran. 2020;3(2):289-95.

35. Suhandiah S, Sudarmaningtyas $P$, Ayuningtyas A. Pelatihan E-Learning Bagi Guru Untuk Optimalisasi Pembelajaran Generasi Z. Aksiologiya J Pengabdi Kpd Masy. 2019;4(1):108-17.

36. de Oliveira Dias M, Lopes R, Teles AC. Will virtual replace classroom teaching? Lessons from virtual classes via zoom in the times of COVID-19. J Adv Educ Philos. 2020;4(05):208-13.

37. Handayani D. The Application of The PjBL Model uses WhatsApp and Zoom Meetings in Learning. Int $\mathrm{J}$ Chem Educ Res [Internet]. 2020;4(2):46-52. Available from: https://doi.org/10.20885/ijcer.vol4.iss2.art 2

38. Johns C, Mills M. Online mathematics tutoring during the COVID-19 pandemic: Recommendations for best practices. Primus [Internet]. 2021;31(1):99-117. Available from: https://doi.org/10.1080/10511970.2020.18 18336

39. Sustiningsih S. Penerapan Pendekatan Kontekstual Melalui Zoom Cloud Meeting untuk Meningkatkan Pemahaman Konsep Matematis. JIRA J Inov dan Ris Akad. 2021;2(2):236-41. 
Naili Darojatil Lathifah et.al. Zoom cloud meeting-based learning model needs analysis to improve mathematical communication ability of elementary school students.

40. Ismawati D, Prasetyo I. Efektivitas pembelajaran menggunakan video zoom cloud meeting pada anak usia dini era pandemi covid-19. J Obs J Pendidik Anak Usia Dini. 2020;5(1):665-75.

41. Tarmizi RA, Bayat S. Collaborative problem-based learning in mathematics: A cognitive load perspective. ProcediaSocial Behav Sci. 2012;32:344-50.

42. Pertiwi I, Sofi'i I. Pengembangan Model Pembelajaran Matematika Berbasis Masalah untuk SMK untuk Siswa Kelas X SMK. In: PROCEEDINGS. 2020.

43. Rahmawati F. Pengaruh Pendekatan Pendidikan Realistik Matematika dalam Meningkatkan Kemampuan Komunikasi Matematis Siswa Sekolah Dasar. Pros
SEMIRATA $2013 \quad$ [Internet]. 2013;1(1):225-38. Available from: http://jurnal.fmipa.unila.ac.id/index.php/se mirata/article/view/882

44. Andriani S. Upaya Peningkatan Kemampuan Komunikasi Matematis Siswa. J Teach Educ. 2020;1(2):33-8.

How to cite this article: Lathifah ND, Rusdarti, Rochmad. Zoom cloud meetingbased learning model needs analysis to improve mathematical communication ability of elementary school students. International Journal of Research and Review. 2021; 8(11): 155-162. DOI: https://doi.org/10.52403/ijrr. 20211121 